\title{
The Influence of School Leadership on Student Outcomes
}

\author{
Vaughan Cruickshank \\ Faculty of Education, University of Tasmania, Launceston, Australia \\ Email: V.J. Cruickshank@utas.edu.au
}

How to cite this paper: Cruickshank, V. (2017) The Influence of School Leadership on Student Outcomes. Open Journal of Social Sciences, 5, 115-123.

https://doi.org/10.4236/jss.2017.59009

Received: August 16, 2017

Accepted: September 11, 2017

Published: September 14, 2017

Copyright $\odot 2017$ by author and Scientific Research Publishing Inc. This work is licensed under the Creative Commons Attribution International License (CC BY 4.0).

http://creativecommons.org/licenses/by/4.0/

\section{(c) (i) Open Access}

\begin{abstract}
The past 30 years have seen numerous education reforms intended to raise the achievement standards of students. These reforms have resulted in school leadership becoming of great interest in international education. This interest stems from a belief that school leadership can significantly influence the quality of teaching and learning in their schools, and consequently student achievement, by improving the working conditions of their teachers, and the climate and environment of their school. Numerous leadership theories have been presented in education related literature, with transformational leadership and instructional leadership being the preferred styles. This paper will examine the effects of both transformational and instructional leadership styles on improving student outcomes. This analysis will occur through three key points of focus: teaching and learning, the collaborative establishment of school goals and vision, and an awareness of and engagement with external forces affecting their school.
\end{abstract}

\section{Keywords}

Student Outcomes, Instructional Leadership, Transformational Leadership, Schools, Principals

\section{Introduction}

The past 30 years have seen numerous education reforms intended to raise the achievement standards of students. As a result of the complexity and constantly evolving school setting these reforms have created, school leadership becomes of great interest in international education as it is increasingly recognized as having a key role in improving student outcomes (Day, Gu \& Sammons, 2016 [1]; Mulford, 2008 [2]). Relevant literature (e.g., Heck \& Hallinger, 2014 [3]; Dhuey \& Smith, 2014 [4]) has demonstrated the influence of teacher quality on student 
achievement. Researcher interest (e.g., Pont, Nusche \& Hunter, 2008 [5]; Shatzer, Caldarella, Hallam \& Brown, 2014 [6]) in school leadership stems from the belief that principal's leadership style can make a substantial difference to the quality of teaching and learning in their schools, and consequently student achievement, by improving the working conditions of their teachers, and the climate and environment of their school. Indeed, research (e.g., Leithwood, Jantzi \& McElheron-Hopkins, 2006) [7] has suggested that leadership style is the second biggest influence on student learning, just behind classroom teaching. Additionally, Hallinger's (2010) [8] review of empirical research on school leadership inferred that leaders can have indirect or mediated positive effects on student achievement by building a collaborative organizational learning culture, and helping to develop the leadership capacities of staff and community. These stakeholders such as parents and teachers can then assist with the creation of a positive school climate that promotes teaching and learning, and consequently student's achievement.

Instructional leadership and transformational leadership are the most regularly cited theories in education related literature (Robinson et al., 2008) [9]. Researchers have endorsed both of these theories as appropriate models of leadership for school principals (e.g., Hallinger, 2003 [10]; Shatzer et al., 2014 [6]). Although there is some overlap between these theories, there are also distinct differences. These situations could confuse school leaders looking for the best model to improve the achievement of their students. This paper will examine the benefits of both instructional and transformational leadership styles for contributing to student outcomes. This analysis will occur through three key points of focus: teaching and learning, the collaborative establishment of school goals and vision, and an awareness of and engagement with external forces affecting their school.

\section{Instructional and Transformational Leadership Theories}

Instructional leadership focuses on the academic progress of students. These foci include the value of creating clear educational goals, planning the curriculum, and evaluating the quality of teachers and their teaching. This model infers that a principals' efforts should be concentrated on the promotion of better outcomes for students, and the importance of improving the quality of classroom teaching and learning (Day et al., 2016) [1]. More specifically, Hallinger (2003) [10] conceptualized instructional leadership as involving three key goals: 1) defining the school's goals, 2) supervising the delivery of the curriculum, and 3) encouraging a positive school learning environment. Research on instructional leadership (e.g., Robinson et al., 2008 [9], Shatzer et al., 2014 [6]) has concluded that instructional leadership can influence student achievement, primarily through improvements to teacher's work conditions and school culture. These studies have concluded that it can have a more noticeable effect on student achievement than transformational leadership, primarily because it places more of an emphasis on the quality of teachers and their teaching. 
Transformational leadership focuses on establishing school culture and vision to enhance the quality of school teaching and learning, develop people, and improve the organization (Shatzer et al., 2014) [6]. Transformation school principals identify and share school vision, lead and inspire others by example, create a culture of learning, and encourage staff members to undertake professional development. Shatzer et al. noted that transformational leadership theory focuses on four key areas: 1) inspirational motivation, 2) individualized consideration, 3) idealized influence (charisma), and 4) intellectual stimulation. A greater emphasis on people has been shown to positively influence the school environment, teachers' attitude and satisfaction (Bogler, 2005 [11]; Griffith, 2004 [12]). While transformational leadership can strongly influence teachers, numerous studies (e.g., Leithwood \& Jantzi, 2006 [13]; Ross \& Gray, 2006 [14]) have concluded that these positive impacts have a much weaker effect on student achievement.

Instructional and transformational leadership differ in several key ways. Instructional leadership uses a top down approach where leaders are the predominant decision makers (Hallinger, 2003) [10], while transformational leadership offers a more distributed or bottom up approach. An example of this distinction would be instructional leaders managing and rewarding their staff as they work toward a predetermined objective, whereas transformational leaders would involve their staff in the creation of a common vision, and inspire them to achieve it more independently. Secondly, instructional leadership prioritizes making changes with core curriculum, whereas transformational leaders use the shared vision they have created with their staff to support change and guide school reforms. This paper will now turn to the analysis of the benefits of both instructional and transformational leadership styles for contributing to student outcomes.

\section{A Focus on Teaching and Learning}

If school principals focus more of their influence on improving the quality of teaching and learning in their school, then they are likely to have a far greater influence on student outcomes. Dinham (2008) [15] observed that an explicit focus on teaching and learning was widespread amongst schools where exceptional student outcomes were found. Principals' leadership is a critical factor in creating and maintaining an environment in which teachers could teach, students could learn, and exceptional outcomes could occur (Louis, Leithwood, Wahlstrom, \& Anderson, 2010) [16]. Teacher quality is a key focus of instructional leadership, and this model appears to be better aligned with this research. Indeed, transformational leadership has been criticized (e.g., Marks \& Printy, 2003) [17] for not having adequate emphasis on education.

Despite the influence of school leaders, many researchers (e.g., Mulford, 2008 [2]; Witziers, Bosker \& Krüger, 2003 [18]) have concurred that the effect of school leadership could be indirect. The contributions of principals can be moderated by organizational factors such as teachers, classroom practice and school 
culture. These factors can substantially reduce the direct effect principals have on outcomes attainment by their students. Although multiple forces might mediate the influence of school leadership on the learning of their students, principals can affect the working conditions and motivations of their teachers, who do directly influence classroom practice and student learning (Pont et al., 2008) [5]. Instructional and transformational leadership models overlap on aspects including school culture and teacher experiences, and therefore might both assist leaders in improving student outcomes through their influence over these factors. Involving staff in the development of a shared school vision might positively influence both school culture and teacher experience.

\section{Building and Sharing the School Vision}

School principals need to focus their efforts on different dimensions of leadership in order for their schools to be successful. Leithwood and Day (2007) [19] stated that of all these leadership dimensions, building vision and setting school directions is the dimension that accounts for the largest proportion of leadership effects on student outcomes. Similarly, Robinson (2007) [9] observed that higher performing schools contained leaders who deliberately focused more of their time on communicating clear academic and learning goals. These goals cut through multiple conflicting demands to define what is important, and consequently where to focus staff and student attention and effort. Leaders can influence both teachers and the way they work by focusing their staff on the school's academic improvement, and making achieving school goals a key focus of everyday practices and procedures. Instructional and transformational leadership models both focus on improving school culture in order to improve student outcomes, and could therefore be of assistance to school leaders looking to develop in this area. Transformational leadership might be of most use because of its greater emphasis on using shared vision to guide reform, and enhance the quality of teaching and learning in schools.

To be effective in building a school vision, school leaders need an ability to communicate their vision for their school in a way that engages other key stakeholders (Mulford \& Edmunds, 2009) [20]. They could also work toward establishing whole staff consensus for school goals and visions, and then effectively communicate these goals to relevant stakeholders in order to give a sense of overall purpose (Silins \& Mulford, 2004) [21]. Principals need to motivate their staff to the point that their personal goals and the schools goals are one and the same. If the principal is unable to do this then the whole school goals will have little motivational value. Principals can therefore justify placing a lot of their time and focus in this area. Transformational leadership would be best suited to providing such motivation because it best aligns with these research findings. The more distributed or bottom up approach of transformational leadership allows teachers to be more involved in the creation of a common school vision, and consequently be more intrinsically motivated to achieve it. These teachers 
are then more likely to display exemplary follower behaviors such as independence, engagement and positivity (Cruickshank, 2017) [22], which (Kelley, 1992)

[23] suggested was vital in order to achieve organizational success.

\section{External Awareness and Engagement}

Many factors can influence the leadership style and effectiveness of school principals. These factors can include their personal abilities and experiences, school and district policies, stakeholder interests, and the family background of the students in the school (Dhuey \& Smith, 2014) [4]. Leithwood and Day (2007) [19] similarly noted that school size and location, and the socio-economic status (SES) of students are additional considerations that can moderate leadership effects. Other literature (e.g., Hallinger, Bickman \& Davis, 1996 [24]; Silins \& Mulford, 2004 [21]) has similarly concluded that principals in higher-SES schools exercised more active instructional leadership than their counterparts in schools serving students of lower SES. For example, the school mission and goals were defined differently in low and high SES effective schools, with low SES schools stressing the mastery of basic skills.

SES can also influence how principals develop community linkages (Hallinger \& Murphy, 1986) [25]. The authors noted that the links between school and home were much stronger in high SES schools. This is important in light of researchers (e.g., Leithwood, Sun \& Pollock, 2017) [26] concluding that parents must be engaged in their children's education because they can have a substantial influence on their academic achievement through their supporting of their learning at home. In higher SES schools, principals constantly sought ways to involve community members whereas in lower SES schools, principals controlled access to the school in an attempt to protect the school's program from external factors that might reduce its effectiveness. These factors undoubtedly influence students' attainment of learning outcomes, but principals also have an important role in encouraging the creation of conditions conducive to effective teaching and learning.

School principals cannot control many of the factors mentioned above. However, principals need to be accountable for the influences to student achievement that do fall within their control (Shatzer et al., 2014) [6]. Dinham (2008) [15] noted that principals of schools that achieved exceptional student outcomes had a strong connection with and understanding of their environment, and actively engaged with it. They regularly utilized their external networks and resources to assist in realizing their vision for the school. Hallinger and Heck (1998) [27] noted that higher achieving schools actively encouraged collaborative decision making that involved a wide range of key stakeholders. Creating a strong shared sense of community is an important component of providing some security in the unstable lives experienced by some children attending particularly challenging schools (Leithwood, Seashore Louis, Anderson \& Wahlstrom, 2004) [28]. This sense of belonging for those living in such circumstances can be vital in 
assisting them to achieve academic, personal and vocational goals.

Successful schools in challenging environments usually have leaders who engage closely with, and are consequently highly trusted by their schools' key stakeholders and surrounding community (Hargreaves, Halasz \& Pont, 2008) [29]. These leaders spent more time in schools with children and placed more focus on improving student welfare and attainment through involvement with partners in their wider community including sports clubs, businesses, and religious groups (Pricewaterhouse Coopers, 2007) [30]. These ideals would appear to align best with a transformational model of leadership; however, leaders must be aware that involving increased numbers of stakeholders can result in uncertainty due to conflicting goals and visions for the school. Instructional leadership can reduce this uncertainty, but does so by reducing opportunities for stakeholder involvement. Gilles (2006) [31] noted that the ability of school principals to act as collaborative transformational leaders can be moderated by personal attributes and school context. Despite these factors the principals in her case studies were eventually able to engage the majority of their followership in a common vision and improve the outcomes of their students. These findings show that school principals must adapt their leadership to the different key features of the communities in which they work, but also that they need to understand how schools and homes interconnect rather than viewing them as separate from each other.

\section{Discussion}

No single leadership approach will be effective for improving all schools and all student outcomes. This notion infers that "improvement requires leaders to enact a wide range of practices" (Leithwood \& Sun, 2012, p. 403) [32]. Effective leadership is a highly responsive and contextualized relational process (Hallinger, 2010) [8]. School principals should ensure they have developed a strong understanding of the unique aspects of their school before they decide on the leadership styles and strategies they will use for improvement. Previous research findings (e.g., Marks \& Printy, 2003 [17]; Robinson et al., 2008 [9]) has found that instructional leadership can account for greater gains in student academic achievement than transformational leadership. However, Marks and Printy also stated that concentrated instructional leadership had minimal impact if leaders only responded to external policy-driven demands of accountability and performance. They concluded that "when transformational and shared instructional leadership coexist in an integrated form of leadership, the influence on school performance, measured by the quality of its pedagogy and the achievement of its students, is substantial" (p. 370). This view is supported by other researchers who have used terms such as "leadership for learning" (Heck \& Hallinger, 2014) [3] and leadership "layering" (Day et al., 2016) [1]. Despite using different terminology, this research concurs that effective leadership should include both the teaching and learning foci of instructional leadership, and the capacity-building 
perspective of transformational leadership. The findings of Day et al. showed that in schools that improved their students' academic outcomes, principals had used an integrated leadership approach to introduce and successfully implement changes that improved teaching and learning. An integrated leadership style is also likely to be a good starting point for other principals looking to improve the academic outcomes of their students.

Relevant literature (e.g., Day et al., 2016 [1]; Mulford, 2008 [2]) have concurred that school leaders do have a quantifiable, yet predominantly indirect influence on student outcomes. The impact that school leaders can have on student learning is often moderated by other factors including teacher quality, classroom procedures and school environment. More specifically, effective transformational and instructional leadership is closely linked to enhanced organizational culture and effectiveness, as well as increased teacher engagement and commitment. These factors are strongly linked to improved student outcomes (Orphanos \& Orr, 2014) [33]. Leaders can contribute to improving student outcomes by influencing the environment in which teaching and learning occur, and building capacity for professional learning and change. Outside of the school, leaders can engage with the changing external environments that can influence their schools (Pont et al., 2008) [5]. This paper has put forward the idea that principals can use an integrated leadership approach to improve the achievement of their students by having an increased focus on teaching and learning, collaboratively establishing school goals and vision, and a having a deeper awareness of and more rigorous engagement with the external forces affecting their school.

\section{Suggestions for Future Research}

While there has been extensive research about how classroom and school conditions influence student learning, there has been less focus on how principals can positively influence those conditions (Leithwood \& Day, 2007) [19], in particular, the role of school leaders in increasing teacher effectiveness, and reducing variability in effectiveness across their teachers. Researchers should focus more of their attention on this topic, particularly longitudinal studies, as school improvements can take several years to become evident. Although researchers (e.g., Heck \& Hallinger, 2014) [3] have suggested integrating aspects of instructional and transformational leadership, further evidence is needed that considers these two models within the same context and with the same criteria for assessing student achievement. Conversely, schools across a wide variety of contexts should also be studied in order to identify the ways and degree to which these contexts affect leadership practices.

Numerous school variables can affect student learning and schools need to create synergy across these variables in order to make strong positive changes (Day et al., 2016) [1]. As school leaders are uniquely positioned to facilitate this synergy, determining the best leadership styles and strategies for different contexts should be a key priority for future research. 


\section{References}

[1] Day, C., Gu, Q. and Sammons, P. (2016) The Impact of Leadership on Student Outcomes: How Successful School Leaders Use Transformational and Instructional Strategies to Make a Difference. Educational Administration Quarterly, 52, 221-258. https://doi.org/10.1177/0013161X15616863

[2] Mulford, B. (2008) The Leadership Challenge: Improving Learning in Schools. http://research.acer.edu.au/cgi/viewcontent.cgi?article $=1000 \&$ context=aer

[3] Heck, R. and Hallinger, P. (2014) Modelling the Longitudinal Effects of School Leadership on Teaching and Learning. Journal of Educational Administration, 52, 653-681. https://doi.org/10.1108/JEA-08-2013-0097

[4] Dhuey, E. and Smith, J. (2014) How Important Are School Principals in the Production of Student Achievement? Canadian Journal of Economics/ Revue canadienne déconomique, 47, 634-663. https://doi.org/10.1111/caje.12086

[5] Pont, B., Nusche, D. and Hunter, M. (2008) School Leadership Matters. In: Improving School Leadership: Volume 1 Policy and Practice, OECD, 15-39.

[6] Shatzer, R.H., Caldarella, P., Hallam, P.R. and Brown, B.L. (2014) Comparing the Effects of Instructional and Transformational Leadership on Student Achievement: Implications for Practice. Educational Management Administration \& Leadership, 42, 445-459. https://doi.org/10.1177/1741143213502192

[7] Leithwood, K., Jantzi, D. and McElheron-Hopkins, C. (2006) The Development and Testing of a School Improvement Model. School Effectiveness and School Improvement, 17, 441-464. https://doi.org/10.1080/09243450600743533

[8] Hallinger, P. (2010) Leadership for Learning: What We Have Learned from 30 Years of Empirical Research? Paper presented at the Hong Kong School Principals' Conference. The Hong Kong Institute of Education, Hong Kong.

[9] Robinson, V. (2007) The Impact of Leadership on Student Outcomes: Making Sense of the Evidence. http://research.acer.edu.au/research_conference_2007/5/

[10] Hallinger, P. (2003) Leading Educational Change: Reflections on the Practice of Instructional and Transformational Leadership. Cambridge Journal of Education, 33, 329-352. https://doi.org/10.1080/0305764032000122005

[11] Bogler, R. (2005) Satisfaction of Jewish and Arab Teachers in Israel. The Journal of Social Psychology, 145, 19-34. https://doi.org/10.3200/SOCP.145.1.19-34

[12] Griffith, J. (2004) Relation of Principal Transformational Leadership to School Staff Job Satisfaction, Staff Turnover, and School Performance. Journal of Educational Administration, 42, 333-356. https://doi.org/10.1108/09578230410534667

[13] Leithwood, K. and Jantzi, D. (2006) Transformational School Leadership for Large-Scale Reform: Effects on Students, Teachers, and Their Classroom Practices. School Effectiveness and School Improvement, 17, 201-227. https://doi.org/10.1080/09243450600565829

[14] Ross, J.A. and Gray, P. (2006) Transformational Leadership and Teacher Commitment to Organizational Values: The Mediating Effects of Collective Teacher Efficacy. School Effectiveness and School Improvement, 17, 179-199. https://doi.org/10.1080/09243450600565795

[15] Dinham, S. (2008) What Effective School Leaders Do to Promote Learning? In: Australian Council for Educational Research, How to Get You School Moving and Improving, ACER, Camberwell, 37-60.

[16] Louis, K.S., Leithwood, K., Wahlstrom, K.L. and Anderson, S.E. (2010) Investigating the Links to Improved Student Learning: Final Report of Research Findings to the 
Wallace Foundation. University of Minnesota, Minneapolis.

[17] Marks, H.M. and Printy, S.M. (2003) Principal Leadership and School Performance: An Integration of Transformational and Instructional Leadership. Educational Administration Quarterly, 39, 370-397. https://doi.org/10.1177/0013161X03253412

[18] Witziers, B., Bosker, R.J. and Krüger, M.L. (2003) Educational Leadership and Student Achievement: The Elusive Search for an Association. Educational Administration Quarterly, 39, 398-425. https://doi.org/10.1177/0013161X03253411

[19] Leithwood, K. and Day, C. (2007) Starting with What We Know. In: Day, C. and Leithwood, K., Eds., Successful Principal Leadership in Times of Change, Springer, Dordrecht, 1-15. https://doi.org/10.1007/1-4020-5516-1_1

[20] Mulford, B. and Edmunds, B. (2009) Successful School Principal Ship in Tasmania. http://fcms.its.utas.edu.au/educ/educ/files/SSchool.Principalship.in.TAS.pdf

[21] Silins, H. and Mulford, B. (2004) Schools as Learning Organizations: Effects on Teacher Leadership and Student Outcomes. School Effectiveness and School Improvement, 15, 443-466. https://doi.org/10.1080/09243450512331383272

[22] Cruickshank, V. (2017) Followership in the School Context. Open Journal of Leadership, 6, 95-103.

[23] Kelley, R. (1992) The Power of Followership. Doubleday, New York.

[24] Hallinger, P., Bickman, L. and Davis, D. (1996) School Context, Principal Leadership, and Student Reading Achievement. The Elementary School Journal, 96, 527-549. https://doi.org/10.1086/461843

[25] Hallinger, P. and Murphy, J. (1986) The Social Context of Effective Schools. American Journal of Education, 94, 328-355. https://doi.org/10.1086/443853

[26] Leithwood, K., Sun, J. and Pollock, K., Eds. (2017) How School Leaders Contribute to Student Success: The Four Paths Framework. Springer, New York.

https://doi.org/10.1007/978-3-319-50980-8

[27] Hallinger, P. and Heck, R. (1998) Exploring the Principal's Contribution to School Effectiveness: 1980-1995. School Effectiveness and School Improvement, 9, 157-191. https://doi.org/10.1080/0924345980090203

[28] Leithwood, K., Seashore Louis, K., Anderson, S. and Wahlstrom, K. (2004) How Leadership Influences Student Learning. http://www.wallacefoundation.org/KnowledgeCenter/KnowledgeTopics/CurrentArea sofFocus/EducationLeadership/Pages/HowLeadershipInfluencesStudentLearning.aspx

[29] Hargreaves, A., Halász, G. and Pont, B. (2008) The Finnish Approach to System Leadership. http://www.oecd.org/edu/schoolleadership

[30] PwC (PricewaterhouseCoopers) (2007) Independent Study into School Leadership: Main Report. DfES, London.

[31] Gilles, C. (2006) Transformational Leadership in Challenging Urban Elementary Schools: A Role for Parent Involvement? Leadership and Policy in Schools, 5, 257-282. https://doi.org/10.1080/15700760600805865

[32] Leithwood, K.A. and Sun, J. (2012) The Nature and Effects of Transformational School Leadership: A Meta-Analytic Review of Unpublished Research. Educational Administration Quarterly, 48, 387-423. https://doi.org/10.1177/0013161X11436268

[33] Orphanos, S. and Orr, M.T. (2014) Learning Leadership Matters: The Influence of Innovative School Leadership Preparation on Teachers' Experiences and Outcomes. Educational Management Administration \& Leadership, 42, 680-700.

https://doi.org/10.1177/1741143213502187 
Submit or recommend next manuscript to SCIRP and we will provide best service for you:

Accepting pre-submission inquiries through Email, Facebook, LinkedIn, Twitter, etc. A wide selection of journals (inclusive of 9 subjects, more than 200 journals)

Providing 24-hour high-quality service

User-friendly online submission system

Fair and swift peer-review system

Efficient typesetting and proofreading procedure

Display of the result of downloads and visits, as well as the number of cited articles Maximum dissemination of your research work

Submit your manuscript at: http://papersubmission.scirp.org/

Or contact jss@scirp.org 